\title{
Oral infeksjon og systemsykdom
}

\section{Orale infeksjoner er assosiert med \\ en rekke systemiske sykdommer.}

Journal of Oral Microbiology har nettopp utgitt et temanummer om sammenhengen mellom oral infeksjon og systemiske sykdommer. De åtte artiklene er fritt tilgjengelig på Internett (1).

I én av artiklene påpekes det at mens dyslipidemi lenge har stått i sentrum for diskusjonen omkring patogenesen ved hjerte- og karsykdom, er infeksjoner, inklusive de som forårsakes av orale bakterier, nå hevdet å kunne spille en viktig rolle (2). Forfatterne gir en oversikt over vert-bakterie-interaksjoner ved tannløsningssykdom (periodontitt) og virulensfaktorer hos orale bakterier før de foreslår mekanismer som orale bakterier kan benytte under utvikling av hjerte- og karsykdom.

Redaktørene i American Journal of Cardiology og Journal of Periodontology anbefalte i 2009 at leger og periodontister som behandler pasienter med hjerte- og karsykdom bør samarbeide tett for å redusere sykdomsrisikoen (3).
Ingar Olsen
ingar.olsen@odont.uio.no
Universitetet i Oslo

\section{Litteratur}
1. Systemic disease and oral bacteria. J Oral Micro- biol. www.journaloforalmicrobiology.net (6.2.2011)
. Leishman SJ, Do HL, Ford PJ. Cardiovascular disease and the role of oral bacteria. J Oral Micro- biol 2010, 2: 5781. DOI: 10.3402/jom.v2i0.5781.
3. Friedewald VE, Kornman KS, Beck JD et al. The American Journal of Cardiology and Journal of Periodontology Editors' Consensus: periodon- titis and atherosclerotic cardiovascular disease. Am J Cardiol 2009; 104: 59-68.

CT kan vise risiko for anastomoselekkasje ved kolorektalkirurgi

Anastomoselekkasje forekommer hos 2-24\% ved kolorektalkirurgi og er forbundet med høy mortalitet. Pasienter med høy kalsiumskår i arterier har økt risiko for anastomoselekkasje, ifølge en ny studie (Am J Surg 2010: 10.1016) j.amjsurg.2010.01.033).

Kalsiumskår er et mål for aterosklerose. Skåren ble bestemt ut fra en preoperativ CT-undersøkelse av 122 pasienter som hadde fått primær kolorektal anastomose.

De som fikk anastomoselekkasje $(n=11)$ hadde signifikant høyere kalsiumskår enn de andre. En slik korrelasjon mellom kalsiumskår og lekkasje er en spennende hypotese, men må bekreftes i større og prospektive studier, ifølge en kommentar i Ugeskrift for Læger (2011; 173: 407).

\section{Fedmekirurgi kan reversere erektil dysfunksjon}

Sykelig overvekt hos menn kan føre til seksuell dysfunksjon. Årsaken er sannsynligvis multifaktoriell. Nå har brasilianske forskere sett på endringer i kjønnshormonnivåer og i erektil funksjon hos 20 menn med $\mathrm{BMI}>40 \mathrm{~kg} / \mathrm{m}^{2}$ (Int J Androl 2010; 33: 736-44).

Ti personer gjennomgikk livsstilsintervensjon i fire måneder og ble deretter operert med gastrisk bypass. De andre ti (kontrollpersonene) ble kun fulgt opp med generelle råd om kosthold og fysisk aktivitet. En BMI-reduksjon på $12,7 \mathrm{~kg} / \mathrm{m}^{2}$ etter fire måneders livsstilsintervensjon ble ikke ledsaget av endringer i hormonverdier eller seksuell funksjon. 20 måneder etter operasjonen var reduksjonen i BMI $24,7 \mathrm{~kg} / \mathrm{m}^{2}$, mot $0,7 \mathrm{~kg} / \mathrm{m}^{2}$ i kontrollgruppen, og det ble rapportert økt skår i erektil funksjon og økte nivåer av testosteron.

\section{Slag mot brystet som årsak til hjertestans}

\section{Et kraftig slag mot brystet kan gi malign hjertearytmi, også kalt commotio cordis. En rekke tilfeller er beskrevet i USA, mens tilstanden nærmest er ukjent i Europa.}

Kun ett tilfelle av commotio cordis innen europeisk idrett er beskrevet de siste 50 årene, mens 224 tilfeller er registrert i USA (1). Tilstanden er en av de vanligste årsakene til idrettsrelatert hjertestans hos unge i Statene. Forskjellen kan delvis forklares av høyere forekomst i typisk amerikanske idretter som baseball og ishockey. Imidlertid er ishockey og liknende idretter med risiko for hard kroppskontakt vanlig i Europa også. En mer sannsynlig forklaring er at tilstanden er underkjent $i$ vår verdensdel. Commotio cordis vil trolig bli vanligere også her pga. økende hastighet og intensitet i moderne idrett.

Eksperimentelle studier har gitt interessant kunnskap om hvordan hjertestans kan induseres. Sannsynligheten for hjertestans øker når slaget treffer over hjertekonturen og på et uheldig tidspunkt $\mathrm{i}$ hjertets rytmesyklus, dvs. i vulnerable del av repolariseringsfasen som på EKG ses rett før T-takken. Moderat harde og moderat raske slag øker sannsynligheten for malign arytmi, likeledes harde, kompakte prosjektiler. Slaget kan øke trykket i venstre ventrikkel, noe som kan deformere cellemembranen, som igjen kan aktivere den $\mathrm{K}^{+}{ }_{\text {ATP- }}$ avhengige ionekanalen og indusere malign arytmi.

Prognosen ved commotio cordis har vært dårlig, men den er blitt bedre enn den var i 1990-årene. Årsaken til dette kan være økt bevissthet om tilstanden og at man derfor behandler riktigere og raskere. Akuttbehandlingen er umiddelbar hjerte-lunge-redning.

\section{Erik Ekker Solberg}

erik.solberg@diakonsyk.no

Medisinsk avdeling

Diakonhjemmet Sykehus

\section{Litteratur}

1. Solberg EE, Embrå BI, Börjesson M et al. Commotio cordis - underrecognised in Europe? A case report and review. Eur J Cardiovasc Prev Rehabil, DOI:10.1177/1741826710389363. 